\title{
„I nie powiem, żeby to były jakieś takie spotkania z Mistrzami": relacje z innymi przedstawicielami dziedziny a rozwój zawodowy w narracjach polskich reżyserek
}

\begin{abstract}
Abstrakt
Autorka opracowania referuje fragmenty badań jakościowych prowadzonych wśród polskich - czynnych zawodowo - reżyserek filmowych, teatralnych i telewizyjnych. Artykuł został podzielony na trzy części: wprowadzenie teoretyczne, metodologiczne i organizacyjne aspekty badań, raport z badań własnych. W artykule szkicowo zaprezentowany został model rozwoju zawodowego (cztery etapy / obszary rozwoju profesjonalnego) oraz znaczenie innych przedstawicieli reżyserii dla rozwoju zawodowego reżyserek, ze szczególnym omówieniem pierwszego etapu - orientowanie się w zawodzie.
\end{abstract}

Słowa kluczowe: reżyserki, rozwój zawodowy, badania jakościowe, ważni inni.

\section{"And I will not say that these were any such meetings with masters": Relations with other Representatives of the Field, and Professional Development in the Narrations of Polish Female Directors}

\begin{abstract}
The author of the study refers to fragments of qualitative research conducted among Polish - professionally active - film, theatre and television directors. The article has been divided into three parts: theoretical, methodological and organizational aspects of research, selected conclusions from the author's own research. The article presents
\end{abstract}

* Uniwersytet Łódzki, Wydział Nauk o Wychowaniu. 
a sketchy model of professional development (four stages / areas of professional development) and the importance of other directors for moving in the professional hierarchy, with a special discussion of the first stage - orientation in the profession / in the field of creativity.

Keywords: directors, professional development, qualitative research, important other.

\section{Wprowadzenie}

Podstawę niniejszego artykułu stanowią badania jakościowe ${ }^{1}$ prowadzone wśród polskich - czynnych zawodowo - reżyserek filmowych, teatralnych i telewizyjnych. Odwołują się tutaj do rezultatów badań związanych z wybranym wątkiem biograficznym, którym jest znaczenie relacji z innymi przedstawicielami reżyserii dla rozwoju zawodowego rozmówczyń. Wątek ten pojawił się we wszystkich wywiadach, choć różnie wybrzmiewał u przedstawicielek kolejnych pokoleń reżyserek. Tekst nie zawiera wyczerpującej analizy dróg zawodowych polskich reżyserek. Pragnę wzbogacić wątki biograficzne nad twórczością, w których nieczęsto podejmuje się wątek artystycznej twórczości profesjonalnej, rozwoju profesjonalnego oraz dynamizujących go czynników - z perspektywy samych twórców.

Reżyseria to nadal jedna z najbardziej zmaskulinizowanych profesji artystycznych. Nieobecność kobiet w kinie i teatrze polskim mogła być związana z niepisanymi zasadami panującymi w środowisku filmowym. Kobiety delegowano do zadań twórczych o mniejszym znaczeniu (np. filmy dokumentalne, filmy i przedstawienia dla dzieci oraz młodzieży), pełniły więc funkcje pomocnicze (np. drugi reżyser, producentka) czy spotykały się z niepoważnym traktowaniem i nieprzyjaznymi przekonaniami na temat posiadanych predyspozycji do zawodu reżysera (Tomasik 2004; Wejbert-Wąsiewicz 2015a, 2015b; Talarczyk-Gubała 2013a, 2013b; Modrzejewska-Świgulska 2018). Tym bardziej intryguje mnie poznawanie i opisywanie: w jaki sposób reżyserki negocjują swoje miejsce w świecie filmu i teatru, w jaki sposób pokonują trudności na drodze do samodzielnej kariery, jakich momentów przełomowych doświadczają i jaką rolę przypisują innym przedstawicielom pola filmowego i teatralnego w narracjach o swojej drodze zawodowej oraz jak wyglądają realia pracy i codzienność zawodowa reżyserek.

Jednym z elementów strukturalnej analizy materiałów (auto)biograficznych - a do takich zaliczam pozyskane materiały badawcze - jest identyfikacja doradców biograficznych, ważnych innych, znaczacych innych, mniej ważnych innych czy

\footnotetext{
1 Przyjmuję rozumienie badań jakościowych za: Denzin, Lincoln (2009: 21-57).
} 
orientujących innych (Denzin 1966; Urbaniak-Zając, Kos 2013). To również istotny wątek badań nad twórczością profesjonalną i wybitną, wskazuje się bowiem znaczącą rolę rodziców, opiekunów w procesie socjalizacji oraz nauki wybranej dziedziny twórczości (naukowej, artystycznej) przez przyszłych twórców (Gardner 1993; Całek 2012). W literaturze podkreśla się niejednoznaczny charakter relacji przyszłych twórców z autorytetami - mistrzami w danej dziedzinie - wzmacniający i inspirujący, jednocześnie emocjonalnie trudny. Zwykle jednak opisuje się pozytywny wpływ mentorów i wzorów osobowych na rozwój talentu, planowanie kariery, wprowadzenie do środowiska oraz uwrażliwianie na formalne i nieformalne zasady rządzących wybraną dziedziną twórczości (Simonton 2010; Gardner 1993; Galenson 2009; Całek 2012; Okraj 2017; Lebuda, Csíkszentmihályi 2018). Spotkanie z autorytetem i jego sposobem myślenia Krzysztof J. Szmidt określa jako „doniosłe spotkanie”, bowiem krystalizuje dalszy rozwój zawodowy, „otwiera drzwi do świata nowych wartości i aktywności" (Szmidt 2019: 68). Bywa, że takie spotkania doświadczane są jako „epifanie”, „doświadczenia krystalizujące”, „objawienia”, "odkrycia”, „momenty zwrotne”, bo re-orientują sposób myślenia i działania, co ostatecznie znajduje odzwierciedlenie w wyborze tematów, strategii i instrumentarium badawczego czy repertuarze muzyków, sposobach obrazowania świata i stosowanych środków wyrazu u artystów wizualnych (Kafar 2011: 42-46). Szmidt (2017: 181), omawiając epifanie i doświadczenia krystalizujące w biografii twórczej, pisze:

W tym sensie doświadczenie tego rodzaju krystalizuje dalszy rozwój zarówno co do jego zasadniczych celów, jak i sposobów do nich prowadzących. Przeżycie krystalizujące jest na ogół jawną, widoczną reakcją na jakieś określone treści lub właściwości danej dziedziny (...). Prowadzi jednak u twórcy do (...) przeobrażeń dotyczących własnych wizji uprawiania twórczości (...).

Relacje z wybitnymi przedstawicielami danej dziedziny są konieczne w procesie rozwoju zawodowego, zwłaszcza na początku drogi twórczej, bez wątpienia ułatwiają nabywanie wiedzy i kompetencji profesjonalnych, pomagają funkcjonować w środowisku (np. nawiązywać kontakty, uczyć się skutecznych wzorów działania). Badania prowadzone wśród noblistów oraz wybitnych muzyków-solistów potwierdzają regułę - „najlepsi” poszukują wybitnie utalentowanych i zmotywowanych młodych twórców, którzy mogliby kontynuować już rozpoczęte kierunki badań, rozwijać szkołę myślenia, wizję artystyczną (Gardner 1993; Stasiakiewicz 1999; Wagner 2005; Całek 2012). Współpraca przyszłego twórcy z osobami znaczącymi obejmuje następujące obszary (Gardner 1993; Csíkszentmihályi 1996; Wagner 2005; Całek 2012, 2013; Ferenc 2012; Szmidt 2019):

- profesjonalny - dotyczy przekazywania warsztatu, technik tworzenia, wiedzy i umiejętności, nakreślenia problemów i pytań dyskutowanych w danej 
dziedzinie, ustalania celów rozwojowych. Eksperci/mistrzowie, osoby wybitne pomagają rozwijać zainteresowania, potencjał młodego adepta poprzez inspirowanie, dobieranie treści, tematów, repertuaru, zadań;

- środowiskowy - dotyczy poznawania pisanych i niepisanych zasad rządzących wybraną dziedziną. Mentor/opiekun wprowadza w środowiskowy kontekst uprawianej dziedziny, to znaczy m.in. zapoznaje z innymi twórcami, recenzentami/krytykami, informuje o zasadach przyznawania grantów, stypendiów oraz pomaga nawiązywać współpracę i tworzyć alianse;

- administracyjno-organizacyjny - dotyczy krótko i długoterminowego planowania kariery z uwzględnieniem kalendarium profesjonalnego (m.in. konkursy, festiwale, stypendia, staże, wystawy, publikacje, granty), tak aby młody twórca mógł komunikować i konfrontować swoje pomysły oraz osiągnięcia z innymi. Opiekun pomaga ustalać finansowe warunki pracy;

- psychologiczny - dotyczy uświadomionych i nieuświadomionych motywów w relacji, oczekiwań wobec siebie i drugiej strony, wyobrażeń, przypisywanych intencji, obaw, zaufania i szacunku, to ten poziom w dużej mierze decyduje, czy dana osoba zostanie wzorem osobowym. Jest to obszar budowania głębokich relacji zawodowych.

Relacje $\mathrm{z}$ autorytetami naznaczone są również napięciem emocjonalnym i decyzyjnym, które wiążą się z problemem naśladownictwa oraz koniecznością poszukiwania autonomicznej drogi rozwoju przez młodych twórców. Paradoksalnie, „namaszczony” uczeń nierzadko kwestionuje myśli i sposób pracy mistrza (Simonton 2010; Nęcka 2002; Miller, Cohen 2012), podejmuje decyzję o „odejściu” związaną z naturalną koniecznością przemyślenia na nowo swojego miejsca $\mathrm{w}$ danej dziedzinie twórczości. Nierzadko jest to moment przełomowy w biografii twórcy oraz początek znaczących osiągnięć, wytyczenie nowych kierunków poszukiwań w tej dziedzinie (por. Gardner 1993; Kafar 2011; Całek 2012). W koncepcji Modelowego Twórcy Howarda Gardnera ${ }^{2}$, jak pisze Anita Całek: „(...) zerwanie z dotychczasową tradycją jest również zerwaniem ze swoim mistrzem (...)” (2013: 260).

Zachowania i decyzje doświadczonych twórców/mistrzów znajdują więc swoje odzwierciedlenie w przebiegu drogi zawodowej przyszłych twórców, przyczyniają się do radykalnych przemian/metamorfoz biograficznych, np. zmiany dziedziny twórczej. W ten sposób stanowią doświadczenie krystalizujące cele aktywności twórczej i nierzadko cele życia.

\footnotetext{
${ }^{2}$ Koncepcja Modelowego Twórcy Howarda Gardnera powstała na podstawie badań biograficznych wybitnych naukowców, artystów i działaczy społecznych. Badacz wyróżnił w modelu fazy i przebieg procesu twórczego (od intuicji do zakomunikowania idei), zasugerował regułę 10 lat oraz doświadczeń krystalizujących, radykalnych przełomów twórczych czy owocnej asynchronii, które mają kluczowe znaczenie dla twórczości wybitnej i rozwoju danej dziedziny twórczości. Koncepcja została szczegółowo omówiona i zastosowana w praktyce badawczej przez Anitę Całek (zob. Gardner 1988; Gardner 1993; Szmidt, Modrzejewska-Świgulska 2011; Całek 2012, 2013; Szmidt 2013).
} 


\section{Uwagi metodologiczne i przebieg badań}

Nie określam głównej metody badawczej, swoją strategię gromadzenia danych „montuję"3 $\mathrm{z}$ różnych technik badawczych. W swoim projekcie kieruję się przede wszystkim ciekawością i potrzebą dotarcia do zróżnicowanych materiałów dokumentujących uwarunkowania pracy zawodowej polskich reżyserek. Za wiodącą technikę uznałam wywiad swobodny, ponieważ umożliwia koncentrację na wybranym aspekcie badań, daje przestrzeń rozmówcom do przywołania własnych doświadczeń, a badaczowi poruszenia i nawiązywania do treści związanych z tematem badań4 (Kvale 2004; Flick 2010; Denzin, Lincoln 2009; Kaufman 2010). Wywiady rozpoczynam ogólnym pytaniem:

Proszę opowiedzieć mi historię swojej drogi zawodowej, jak to się stało, że wykonuje Pani zawód reżysera.

Nie ograniczam się jednak do rozmów i wywiadów, uczestniczę w planach filmowych (serialu telewizyjnego emitowanego od wielu lat w Polsce, filmu fabularnego), próbach teatralnych, zajęciach na kierunku reżyserii teatralnej, udzielam się w Polskim Stowarzyszeniu Kobiet Filmowców, prowadzę warsztaty wspierające reżyserki w ich pracy zawodowej, czytam wypowiedzi reżyserek o swojej pracy, zamieszczane w prasie i Internecie. Materiał pochodzący z wywiadów swobodnych i rozmów (bezpośrednich, telefonicznych) uzupełniam więc prowadzeniem obserwacji bezpośredniej, bowiem umożliwia ona głębsze poznawanie „naturalnego” środowiska pracy twórczej (por. Konecki 2000; Lutyński 2000; Frankfort-Nachmias, Nachmias 2001). Dodatkowo sięgam po zastane materiały (auto)biograficzne - wspomnienia, wywiady, artykuły dotyczące pracy twórczej reżyserek. Wypowiedzi artystek rozumiem jako społeczną praktykę komunikacyjną. Zakładam, że są zapisem określonej świadomości społecznej i stanowią odpowiedni materiał uzupełniający treści wywiadów. W materiałach zastanych poszukuję podobnych wątków poruszanych przez rozmówczynie, bo traktuję analizę wspomnianych tekstów jako sposób na triangulowanie danych zdobytych na drodze rozmów bezpośrednich. Obserwuję, słucham, pytam, działam po to, aby tworzyć jak najbardziej szczegółową „mapę” na temat kontekstów pracy polskich reżyserek, czyli - jak piszą Norman K. Denzin i Yvonna S. Lincoln (2009: 26) - „wzór dla interpretacyjnego doświadczenia”. Oczywiście zdaję sobie sprawę, że „mapa” to nie to samo co „terytorium”, dlatego cały czas pozostaję w kontakcie ze środowiskiem reżyserek, aby móc w jego kręgu dyskutować efekty badań własnych - proponowane hipotezy, uogólnienia, modele. W tekście rekonstruuję opinie pochodzące z 16 wywiadów przeprowadzonych z reżyserkami filmowymi, teatralnymi i telewi-

\footnotetext{
${ }^{3}$ Za: Denzin i Lincoln (2009).

${ }^{4}$ Szerzej o interesujących mnie kwestiach piszę w tekście (zob. Modrzejewska-Świgulska 2018).
} 
zyjnymi. Są to zarówno czynne już zawodowo studentki oraz absolwentki wyższych szkół artystycznych, które kończyły szkoły artystyczne w różnym czasie na przestrzeni kilkudziesięciu lat, najstarsza z nich jeszcze w latach 50., najmłodsze na początku XXI w. Wszystkie moje rozmówczynie mieszkają i pracują w Polsce, niektóre również za granicą. Nagrane wywiady poddane zostały standardowej transkrypcji, interesowało mnie „co” mówią rozmówczynie, a nie jak rekonstruują zdarzenia. Zebrane wywiady poddałam trzyetapowej analizie i interpretacji: 1) analizie w obrębie poszczególnych przypadków (od swobodnych skojarzeń, poprzez uporządkowanie formalne tekstu, do opisu strukturalnego); 2) porównywaniu wątków tematycznych pojawiających się $\mathrm{w}$ wywiadach (szukanie podobieństw i różnic); 3) uogólnieniu poprzez tworzenie typów biografii zawodowych, hipotetycznych modeli obrazujących uwarunkowania pracy twórczej reżyserek (por. Miles, Huberman 2000; Bertaux 2012; Urbaniak-Zając, Kos 2013; Modrzejewska-Świgulska 2016, 2018) ${ }^{5}$.

\section{Rozwój zawodowy reżyserek - propozycja modelu}

W narracjach odnajduję podzielane przez rozmówczynie doświadczenia związane z funkcjonowaniem w świecie filmu i teatru. Opisy rozwoju zawodowego różnią się w zależności od czasu ukończenia szkoły, aktualnej sytuacji zawodowej i realizowanych projektów twórczych. Rozmówczynie wskazały kilka elementów znaczących dla rozwoju zawodowego i przemieszczania się w hierarchii środowiska oraz odnoszenia sukcesów w świecie filmu i teatru. Są to przede wszystkim:

- uwarunkowania osobowe, m.in. predyspozycje do konstruktywnego radzenia sobie z sytuacjami stresującymi, zdolności „menadżerskie”, ",iderskie”, wysoka odporność na krytykę;

- uwarunkowania środowiskowe, m.in. inni twórcy/przedstawiciele dziedziny spotykani w różnych momentach kształcenia zawodowego i na dalszych etapach kariery;

- uwarunkowania polityczno-ekonomiczne oraz instytucjonalne, m.in. zmieniający się mecenat państwowy i prywatny, znikające i pojawiające się instytucje.

Mihaly Csíkszentmihályi (1996) w swojej radykalnej teorii przyjmuje założenie: twórczość jest wynikiem interakcji trzech elementów - jednostek (twórców, zespołów badawczych, artystycznych), dziedziny twórczości i pola (środowiska, instytucji). Wieloletni cykl twórczości wybitnej przebiega od jednostek, poprzez selekcję pola i włączenia do dziedziny oryginalnych wytworów, idei.

\footnotetext{
${ }^{5}$ Czytelnik może prześledzić proces analizy danych referowany przeze mnie w kolejnych artykułach (Modrzejewska-Świgulska 2016, 2018; Okraj, Modrzejewska-Świgulska 2018).

6 Wypowiedzi reżyserek zaznaczone zostały w cudzysłowie.
} 
Obserwacja dróg zawodowych reżyserek pozwoliła na zrekonstruowanie modelu rozwoju zawodowego twórczyń, które debiutowały i realizowały karierę w odmiennych kontekstach polityczno-ekonomicznych. Model ma charakter hipotetyczny, wymaga dalszej eksploracji oraz nasycenia danymi. Stanowi jednak duże uproszczenie $\mathrm{w}$ porównaniu z rzeczywistością zawodową opisywaną przez reżyserki podczas rozmów (rycina 1). Proces uczenia się zawodu przez reżyserki obrazuję za pomocą dwóch wymiarów - doświadczenia zawodowego oraz autonomii artystycznej. Wspominane wymiary nie tylko pojawiają się w wywołanych przeze mnie narracjach, ale i wywiadach udzielanych przez reżyserki dla prasy. Tak o swoim dojrzewaniu artystycznym mówi Małgorzata Szumowska, reżyserka, która odnosi znaczące sukcesy w Polsce i za granicą:

(...) Krzysztof Kieślowski, Michael Haneke czy Pedro Almodovar. Oni odnaleźli swój język artystyczny dopiero po latach kręcenia filmów. Mając 46 lat, jest się dojrzałym artystą, zwłaszcza jeśli zaczęło się wcześnie. A ja zaczęłam bardzo wcześnie, bo miałam tylko 25 lat. (...) Długo zdobywałam doświadczenie, ale też nabierałam dystansu7. [wyróżnienie M. M.-Ś.]

Pierwszy wymiar modelu dotyczy nabywania doświadczenia i tworzy go dymensja: duże doświadczenie zawodowe - brak doświadczenia zawodowego (lina pionowa, rycina 1). Doświadczenie zawodowe opisywane jest jako proces uczenia się poprzez:

„Dosyć długo byłam asystentem reżysera i drugim reżyserem”

- zdobywanie szeroko pojętej wiedzy o filmie i teatrze;

- nabywanie kompetencji „rzemieślniczych”, „technicznych” związanych z reżyserowaniem filmów, przedstawień teatralnych i telewizyjnych;

- realizację wielu różnych zadań reżyserskich (np. komercyjnych, autorskich);

- terminowanie u wybitnych twórców, pełnienie funkcji pomocniczych na planach filmowych i próbach teatralnych;

- budowanie sieci kontaktów (kooperacji i aliansów artystycznych, duetów twórczych);

- nabywanie „odporności” psychicznej na trudne sytuacje zawodowe;

- poznawanie formalnych i nieformalnych zasad panujących w środowisku.

Drugi wymiar modelu opisuje proces budowania autonomii zawodowej/artystycznej i tworzy go dymensja: brak autonomii - ugruntowana autonomia (rozumiana jako możliwość realizowania autorskich pomysłów), jest charakteryzowany następującymi właściwościami (linia pozioma, rycina 1):

\footnotetext{
${ }^{7}$ Kino z przypadku, filmowiec z zaskoczenie, rozmowa z Małgorzatą Szumowską, „Forbes Women” 2019, 1, s. 31 .
} 
„Ja wiem, jakie filmy chcę robić"

- poczuciem bycia samodzielnym twórcą;

- płynnym realizowaniem zadań komercyjnych i autorskich, a w konsekwencji względnie stabilną sytuacją finansową (na najbliższe 4, 6 lat);

- świadomością własnego języka artystycznego, warsztatu artystycznego, przebiegu procesu twórczego;

- docenianie twórczych umiejętności innych osób ze środowiska;

- pełnieniem roli - nauczyciela, mentora.

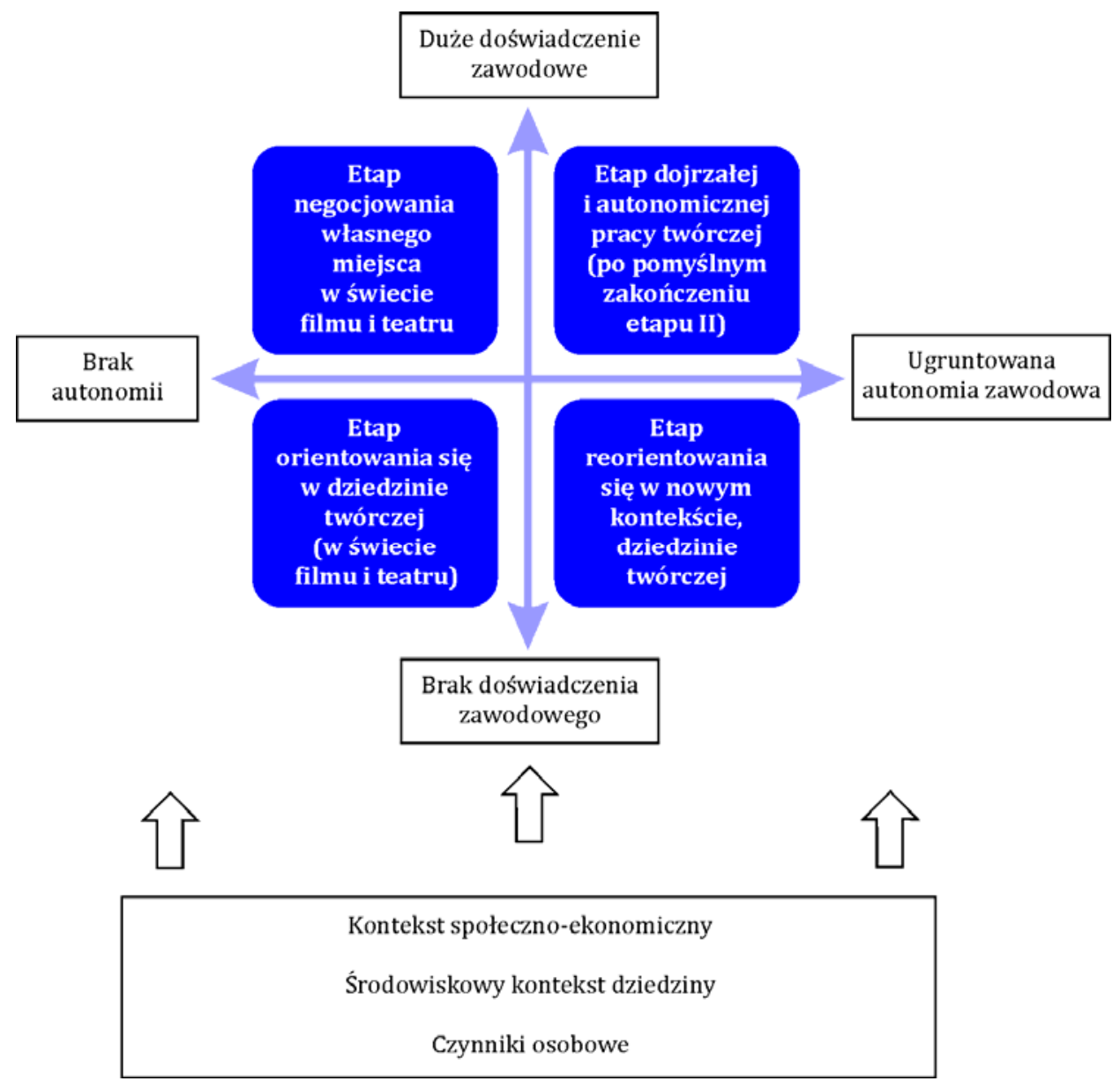

Ryc. 1. Model rozwoju zawodowego reżyserek

Źródło: badania własne. 
Na przecięciu opisanych wyżej wymiarów powstają cztery podstawowe etapy/obszary rozwoju zawodowego. Każdy z etapów cechuje duża dynamika i zróżnicowanie czasowe w przebiegu indywidualnych biografii zawodowych. Na potrzeby tekstu jedynie szkicowo opisuję kolejne etapy rozwoju zawodowego, aby móc wprowadzić wątek relacji narratorek z innymi przedstawicielami dziedziny. Właściwy rozwój zawodowy poprzedza etap przygotowujący, nieuświadomiony, a związany z nabywaniem kapitału kulturowego w domu rodzinnym bądź dzięki nauczycielom i/lub znajomym, którzy inspirowali do obcowania z kulturą wyższą, i sublimowania własnych zainteresowań w obszarze szeroko pojętej humanistyki. Narratorki zwracały uwagę na dwa typy zainteresowań rozwijanych w szkole średniej: artystycznych i/lub humanistycznych (związanych z kształtowaniem gustu literackiego, muzycznego, nabywaniem wiedzy o kulturze) (por. Ślęzak 2009; Całek 2012, 2013; Okraj, Modrzejewska-Świgulska 2018; Okraj 2017; Lebuda, Csíkszentmihályi 2018).

Pierwszy etap to czas orientowania się zawodowego w trakcie edukacji profesjonalnej przypadającej przeważnie na naukę w wyższych szkołach filmowych, teatralnych i telewizyjnych. Rozpoczyna go moment pomyślnego zaliczenia egzaminów wstępnych poprzedzonych procesem przygotowania się do nich. Etap kończy się wraz z ukończeniem edukacji/uzyskaniem dyplomu bądź decyzją o zaprzestaniu nauki w szkole, ale kontynuowaniu pracy twórczej w praktyce. Uzyskanie dyplomu nie jest jednoznaczne z debiutem reżyserskim - samodzielnie wyreżyserowaną produkcją filmową bądź teatralną. Niektóre reżyserki debiutowały już na trzecim, czwartym roku studiów, inne wiele lat po ukończeniu szkoły (np. ponad 20 lat od ukończenia szkoły, jak w przypadku Barbary Sass-Zdort). Orientowanie się w zawodzie narratorki opisują jako uczenie się warsztatu telewizyjnego, filmowego czy teatralnego (nabywanie doświadczenia), ale przede wszystkim „hartowanie emocjonalne” do samodzielnej pracy w zawodzie.

Drugi etap zakłada intensywne negocjowanie własnego miejsca w świecie filmu i teatru, a rozpoczyna go realizacja autorskiego projektu reżyserskiego - debiut lub kolejna samodzielna produkcja (film długometrażowy, spektakl na liczącej się scenie teatru państwowego). Reżyserki często nadal współpracują z dojrzałymi twórcami (np. pełnią funkcje pomocnicze w zespołach filmowych), jednocześnie chcą realizować autorskie pomysły, dlatego rezygnują z tej współpracy. Jest to czas, jak określają go rozmówczynie, radzenia sobie poza „murami szkoły” i „czas pukania do drzwi” - czyli przekonywania innych do własnego pomysłu (dzwonienia do dyrektorów teatrów, przedstawiania pomysłów producentom, składania wniosków o dofinansowanie do instytucji pełniących rolę państwowego mecenatu, szukania prywatnych funduszy). Na tym etapie kariera reżyserek może potoczyć się różnie zaowocować dużym sukcesem artystycznym lub w skrajnym przypadku doprowadzić do zmiany zawodu. Pomyślne zakończenie tego etapu pozwala na budowanie dalszej drogi i sukcesy zawodowe. 
Trzeci etap, dojrzałej i autonomicznej pracy twórczej, cechuje intensywna praca nad autorskimi projektami oraz duża mobilność zawodowa. Twórczynie reżyserują na terenie całej Polsce, ale też za granicą, realizując przy tym zróżnicowane projekty, ale naznaczone własną wrażliwością i językiem artystycznym. Rozmówczynie tworzą w sieci kontaktów i projektów, płynnie realizują kolejne autorskie projekty. Mają poczucie ustabilizowanej sytuacji finansowej.

Ostatni, czwarty, etap pojawił się w dwóch narracjach u reżyserek najstarszego pokolenia, a dotyczy konieczności reorientowania się w nowym kontekście dziedzin i środowiska, w którym rozwijały swoją drogę artystyczną. Zmiana sytuacji społeczno-ekonomicznej, dojście do „głosu młodszych kolegów”, a w konsekwencji trudności z pozyskiwaniem funduszy (doświadczenie zdobyte w innych warunkach już nie wystarcza) powodują, że rozmówczynie muszą ponownie odpowiedzieć sobie na pytanie o ich dalsze losy twórcze. Ograniczają własną pracę twórczą (np. reżyserowanie tylko $w$ teatrze, a rezygnacja $z$ pracy na planach filmowych), ale w zamian podejmują aktywność na rzecz uczenia innych (młodych twórców) oraz często pełnią role eksperckie (zob. Modrzejewska-Świgulska 2016, 2018; Okraj, Modrzejewska-Świgulska 2018).

W przekonaniu reżyserek istotnymi czynnikami dynamizującymi rozwój zawodowy są: samodeterminacja, uczenie się kompetencji zawodowych, energia życiowa, przeświadczenie o istotności realizowanych tematów oraz współpraca z innymi przedstawicielami dziedziny (o czym piszę dalej). Reżyserki, aby zakomunikować własne pomysły, nadać im postać materialną, podejmują bowiem wiele skoordynowanych i heteronomicznych działań we współpracy z innymi przedstawicielami dziedziny (por. Becker 1982). Takie postrzeganie rozwoju zawodowego przywołuje na myśl teorię autodeterminacji Richard Ryan i Edward Deci powstałą na gruncie badań nad motywacją wewnętrzną i zewnętrzną. Badacze wychodzą z założenia, że kluczowe dla rozwoju, również zawodowego, jest zaspokajanie następujących potrzeb: relacji społecznych, kompetencji i autonomii (podejmowanie aktywności zależnych od zainteresowań i zgodnych z własnym systemem wartości) (zob. Chrupała-Pniak, Grabowski 2016; Tokarz 2005).

Zaproponowany model wpisuje się w systemowe koncepcje twórczości, bowiem dla rozwoju zawodowego profesjonalnych twórców w dziedzinie reżyserii mają znaczenie zarówno czynniki makrospołeczne (kulturowe, ekonomiczne i polityczne), jak i osobowe. Ciekawym wątkiem kolejnych analiz będzie porównanie zaproponowanego modelu z już istniejącymi modelami rozwoju twórczości (szczególnie koncepcjami fazowymi i systemowymi) oraz ogólnymi modelami rozwoju zawodowego i nabywania kompetencji profesjonalnych (Myszka-Strychalska 2017). 


\title{
Znaczenie relacji z innymi przedstawicielami reżyserii dla rozwoju zawodowego rozmówczyń
}

\author{
„Stawanie się członkiem kultury oznacza uczenie się nowych rzeczy od innych ludzi”.
}

Michael Tomasello

Narracje reżyserek ujawniły istotne biograficznie interwencje innych przedstawicieli reżyserii spotkanych na kolejnych etapach drogi zawodowej. Wątek uczenia się zawodu od innych przedstawicieli dziedziny, dojrzałych twórców i kolegów stanowi istotny wątek biograficznych badań nad życiem i pracą twórców (zob. m.in. Gardner 1993; Csíkszentmihályi 1996; Całek 2012). Dlatego punktem wyjścia jest dla mnie następujące założenie - przyszłe artystki uczą się zawodu w relacji z innymi przedstawicielami danej profesji (por. Wagner 2005; Ślęzak 2009; Ferenc 2012). Becker, Strauss (1956) (za: Wagner 2005: 22) zakładają:

(...) kariera jest drogą zawodową aktora, składającą się z łańcucha etapów następujących po sobie i różniących się pomiędzy sobą jakością interakcji, w które są zaangażowane osoby należące do otoczenia zawodowego i odgrywają w danym środowisku istotną rolę.

Na każdym z etapów rozwoju zawodowego pojawiają się osoby, których działania dynamizują sytuację zawodową rozmówczyń. Na pierwszym etapie - orientowania się w zawodzie - są to przede wszystkim wykładowcy oraz inni studenci szkół filmowych, teatralnych i telewizyjnych. Obraz tych dwóch grup w opowieściach reżyserek jest dwuznaczny. Wykładowcy z jednej strony inspirują, „pokazują, jak opowiadać dobre historie”, z drugiej strony stosują zastanawiające środki przemocy psychicznej - „wykluczenie”, „ośmieszenie”, „negowanie”, „krzyk”. Dla narratorek, zwłaszcza absolwentek PWSTTiT w Łodzi, takie zachowania są świadomą taktyką edukacyjną i mają „uodpornić na trudną rzeczywistość, kiedy będzie trzeba działać poza szkołą". Relacje z kolegami portretowane są na osi typu: od współpracy („przeglądaliśmy się w sobie”, „uczyliśmy od siebie”) do rywalizacji („czuło się rywalizację między nami”). Negocjowanie swojego miejsca w świecie filmu i teatru, drugi etap rozwoju zawodowego, łączy się w narracjach $\mathrm{z}$ wątkami terminowania u dojrzałych twórców, wybitnych reżyserów oraz zawiązywaniem koalicji czy tandemów twórczych (np. reżyserka - operator). Narratorki podkreślały zespołowy i relacyjny charakter pracy reżysera - na każdym jej etapie, od szukania pomysłów do realizacji ostatecznego produktu. Jednym z kluczowych momentów w biografiach starszych reżyserek filmowych był moment kolaudacji (decyzji zespołu o dalszych losach filmu), który decydował o dalszej karierze ${ }^{8}$. Intensywna

${ }^{8}$ Znana jest historia „przerwanej” kariery Ewy Kruk (Talarczyk-Gubała 2013a). 
i autonomiczna praca twórcza w narracjach wiąże się z wątkiem zmiany roli, a reżyserki same stają się ważnymi innymi dla młodszego pokolenia twórców (poszukują talentów, ciekawych osobowości artystycznych). Na etapie re-orientowania się w zawodzie w narracjach znikają znaczące osoby - pojawia się wątek osamotnienia, buntu wobec „młodszych kolegów” ze środowiska. W tabeli zamieszczam charakterystykę relacji z innymi przedstawicielami i skutki biograficzne tych spotkań (tabela 1).

Poniżej koncentruję się na relacjach reżyserek z innymi przedstawicielami dziedziny spotkanymi na pierwszym etapie rozwoju zawodowego - orientowania się w zawodzie, czyli podczas edukacji profesjonalnej rozumianej tutaj jako studiowanie i/lub terminowanie u osoby mającej wysoki status w środowisku. Opowieści o relacjach z wykładowcami ujawniły klasyczną opozycję między systemem a podmiotem realizującym swoje cele twórcze. Zrekonstruowałam trzy typy postaw: poszukiwanie wsparcia w systemie, potrzebę pracy poza systemem oraz potrzebę zmiany systemu. Za przykłady posłużą poniższe historie reprezentantek średniego i najmłodszego pokolenia reżyserek.

Historia I - Ja jestem człowiekiem, który musi być w systemie, czyli o reżyserowaniu współzależnym/,w systemie”

W jednym z tekstów naukowych twórczość rozmówczyni przypisana została do pokolenia reżyserów, które „zmarnowało swoje talenty”. Kończy ona szkołę pod koniec XX w., debiutuje krótkim metrażem zaraz na początku wieku XXI. Jej pierwsze filmy otrzymały bardzo dobre recenzje i międzynarodowe nagrody. Mimo tego to do tej pory nie zrealizowała ona filmu długometrażowego/kinowego. Określenie „zmarnowało swoje talenty” nabiera innego znaczenia w kontekście poniższych słów narratorki:

Nasze roczniki wchodziły w czarną dziurę, pojawiały się zalążki nowych struktur, ale nie wiadomo było dokąd pójść ze swoimi pomysłami, nie było starego i nie było nowego.

Osoby, które kończyły szkoły filmowe w tym czasie, rozpoczynały drogę zawodową w niedogodnych warunkach - stary system i zasady finansowania filmów (mecenat państwowy) skończyły się ostatecznie po 1989 r., a nowe struktury nie zostały jeszcze wykształcone (np. Polski Instytut Sztuki Filmowej został powołany dopiero w 2005 r.). Historia narratorki staje się więc również historią polskiej rzeczywistości filmowo-teatralnej. Należy ona do ostatniego pokolenia uczonego przez wybitnych twórców polskiego kina, m.in. Wojciecha Hasa ${ }^{10}$, Henryka Klubę ${ }^{11}$,

\footnotetext{
${ }^{9}$ Nie podaję przypisu, aby zapewnić anonimowość mojej rozmówczyni.

${ }^{10}$ Wojciech Jerzy Has (1925-2000).

11 Henryk Kluba (1931-2005).
} 


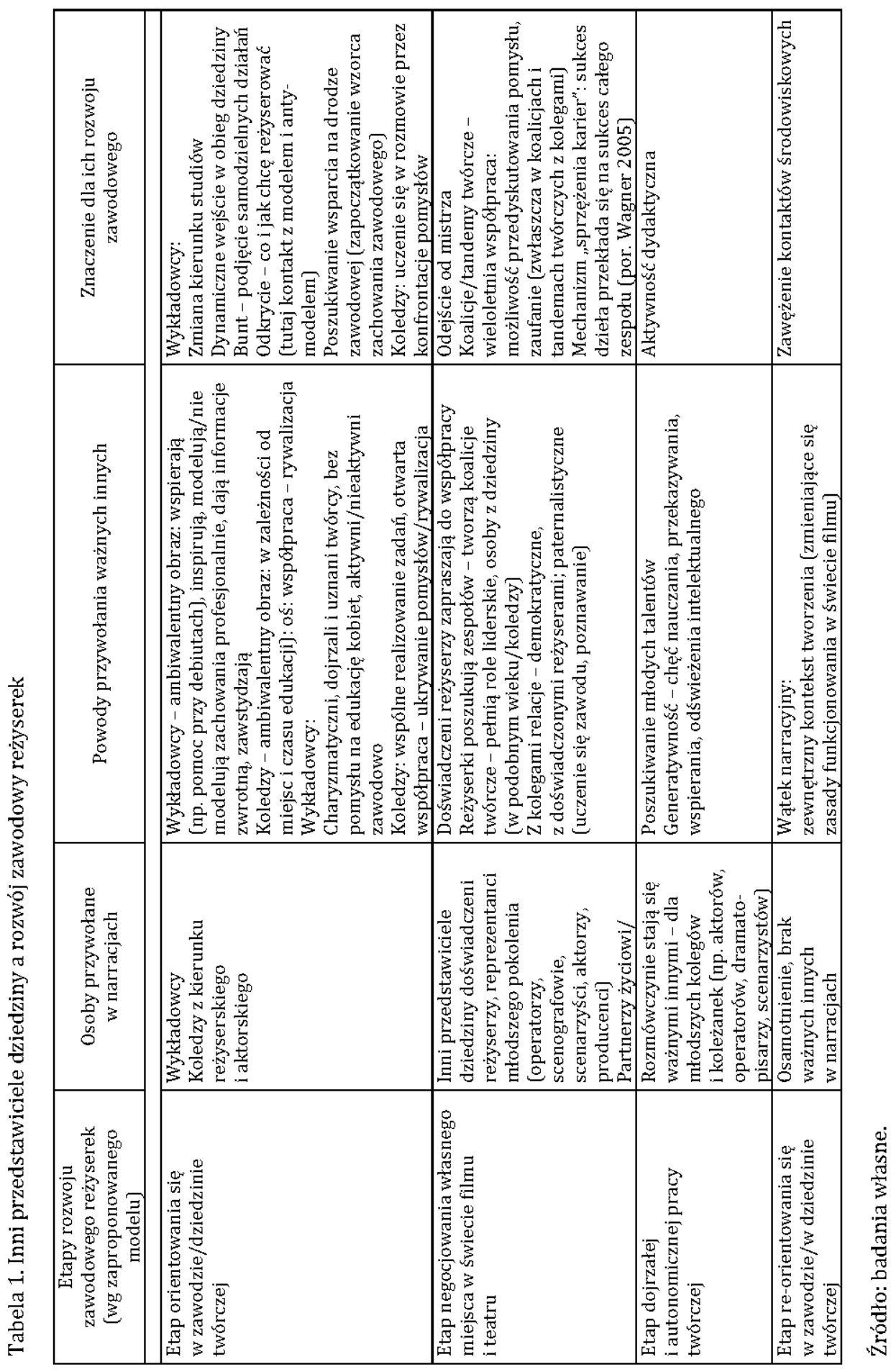


Krzysztofa Kieślowskiego ${ }^{12}$. Doświadcza silnych i niejednoznacznych emocji w relacjach z wykładowcami:

Najważniejsi byli ludzie, których spotkałam tutaj (chodzi o PWSFTiT - ...), z mojego roku i z różnych lat i profesorowie, których tutaj spotkałam. Miałam dużo szczęścia, że spotkałam takich, a nie innych. Uczył mnie Henryk Kluba, Wojciech Hass, potem Mariusz Grzegorzek, Andrzej Wajda, a potem jeszcze Kieślowski mnie uczył, miał z nami zajęcia przez rok. To była bardzo emocjonalna podróż, też toksyczna, bo szkoła wyzwala w ludziach bardzo trudne emocje. Ja miałam tak, że próbuje coś wydzierać z siebie, próbuje coś zrobić, to musi mieć jeszcze sens, jest oceniane. To jest mieszanka trudnych uczuć. [wyróżnienie M. M.-Ś.]

Narratorka, aby móc się rozwijać twórczo i pracować jako reżyserka, potrzebuje wsparcia autorytetów i instytucji. A więc obraz siebie jako twórczyni buduje w relacji z innymi:

Osoby, które pomagały wniknąć w siebie, np. Krzysztof Kieślowski był słuchaczem (...) jego obecność wyciągnęła, wywołała. Tak jakby nacisnął odpowiedni guzik, wcześniej był chaos, a potem historia się pojawiła.

Celem rozmówczyni jest więc znalezienie dla siebie miejsca w środowisku, po szkole zostaje zatrudniona jako asystentka, po wielu latach wraca na studia doktoranckie:

Ja jestem człowiekiem, który musi być w systemie. Nie potrafię sobie stworzyć sytemu (...)

Stawiam hipotezę, że narratorka nie zrealizowała długometrażowego debiutu, bowiem potrzebowała systemu i działania w polu przyjętych norm, a co więcej wsparcia oraz pozytywnej relacji z autorytetami. Brak tych czynników spowodował wycofanie i kończenie pracy twórczej na etapie pomysłów, szkiców, treatmentu (czyli wizji reżysera).

Niestety jestem zewnątrz sterownym człowiekiem, potrzebuję, wsparcia i pozytywnej reakcji autorytetów.

Historia II - Więc chciałam zrobić poza systemem ten film, czyli o reżyserowaniu niezależnym/,poza systemem”

Autorka tej historii skończyła również PWSFTiT zaledwie kilka lat po przywołanej powyżej narratorce, ale jest to już zupełnie inna historia, opowiedziana z inną

\footnotetext{
${ }^{12}$ Krzysztof Kieślowski (1941-1996).
} 
energią i z innymi emocjami, które wiążą się z nowym kontekstem szkoły filmowej - szkoły bez wielkich nazwisk reżyserów.

Nauczyła mnie tego (szkoła PWSFTiT - M.M.-Ś.), że trzeba walczyć o siebie.

Wykładowcy postrzegani są jako antymodele twórczości reżyserskiej:

I nie powiem, żeby to były jakieś takie spotkania z jakimiś mistrzami. Bo nie mogę powiedzieć, żebym jakiegoś mistrza spotkała w szkole. Wtedy to było tak, że dużo tych wykładowców, to byli ludzie którzy nie robili filmów, starsi wykładowcy. (...) to byli ludzie w zasadzie poza branżą.

W historii pierwszej narratorka, aby rozwijać się zawodowo potrzebuje innych, z kolei w drugiej historii możliwość działania i praktykowania ma większe znaczenie:

I co najlepiej wspominam, (...) to, po co tam w ogóle poszłam, to była ta możliwość robienia filmów.

Dalej dodaje:

Możliwość sprawdzenia siebie, swoich pomysłów w praktyce, czy potrafię to co sobie wymyśliłam przenieść na ekran, co ludzi interesuje i dotyka.

Narratorka postrzega siebie i kolegów jako twórców niezależnych od szkoły, systemu, autorytetów. Stawia sobie cel funkcjonowania poza systemem i strukturami instytucjonalnymi. Podejmuje działania wbrew utartym schematom, chce wytyczyć nowe sposoby postępowania. Działa na rzecz zmiany i wprowadzenia różnicy do sytuacji zastanej, inicjuje nowe praktyki w swojej dziedzinie. „Podmioty sprawcze - zdaniem Katarzyny Iwińskiej (2015) - są zwykle nieświadome zbiorowych konsekwencji własnych działań (...), zwykle podmioty sprawcze z niewiadomych powodów robią krok naprzód wbrew normom, prawu, kulturze (...) i zaczynają w ten sposób motywować do działań grupy społeczne":

Na drugim roku do moich kolegów powiedziałam: chłopaki, robimy film. Olewamy tę całą szkołę, bo my będziemy robić tę szkołę, będziemy te egzaminy sobie zdawać, (...), to my nigdy nie zrobimy filmu, będziemy latami czekać na tę możliwość debiutu. Więc chciałam zrobić poza systemem ten film.

Film, o którym wspomina narratorka, powstał i został bardzo dobrze odebrany, do tej pory rozmówczyni wyreżyserowała dwa długometrażowe filmy fabularne. 
Historia III - Miałam wrażenie, że nasi profesorowie uczq nas, jak nie reżyserować, czyli „zmienić system”

Autorką tej opowieści jest czynna zawodowo reżyserka, badaczka (doktor nauk humanistycznych), wykładowczyni uniwersytecka. W swojej narracji wraca często do wątku nauczania reżyserii (zresztą nie tylko ona ), punktuje nieaktualne metody nauczania, bierność zawodową wykładowców i brak pomysłu na nauczanie reżyserii:

Miałam wrażenie, że nasi profesorowie uczą nas, jak nie reżyserować. Cała nauka, poza życzliwymi wyjątkami, była uczeniem się tego jak nie. Jak nie podchodzić do aktora, jak nie wybierać sobie tematu, jak nie odczytywać tekstu, jak nie myśleć o teatrze. Ta szkoła miała całkowicie nieprzemyślane narzędzia, całkowicie też niedopasowane do tego, $\mathrm{w}$ jakim momencie był wtedy teatr w Polsce i na świecie. Mam wrażenie, że uczono nas trochę bez planu. Jakoś tak bardzo przypadkowo. [wyróżnienie M. M.-Ś.]

Narratorka podkreśla konieczność wypracowania nowych form i metod nauczania reżyserii oraz przeformułowania języka, szczególnie w komunikacji z kobietami na wydziale reżyserii. Demaskuje przejawy niesprawiedliwych przekonań dotyczących kobiet - artystek oraz wszelkich oznak paternalizmu w relacjach pomiędzy studentkami reżyserii a wykładowcami (mężczyznami).

Na przykład pozwalano sobie na uwagi dotyczące wyglądu. Co oczywiście miało być miłe, prawda? Że się kogoś docenia, zauważa jakiś, nie wiem, nowy kolor włosów, okulary, fryzurę. (...) To na przykład było takie niekomfortowe. Dwa, odbywano z nami takie rozmowy, które nie sądzę żeby ktokolwiek tak rozmawiał z kolegami, na przykład o dzieciach. Mówili dziewczynki, szybko zróbcie sobie dziecko. Bo potem będziecie chodzić po ścianach.

Narratorka dostrzega potrzebę kobiet-nauczycielek, które swoim przykładem mogą motywować, podpowiadać rozwiązania, sposoby radzenia sobie $\mathrm{w}$ męskim świecie filmu i teatru.

(...) wśród wykładowców w ogóle nie ma kobiet na reżyserii. No myślę, że to dosyć mocno wpływa, kiedy nie ma w ogóle kobiet, które mogą stać się jakimiś, nie wiem, nauczycielkami, mistrzyniami, tak?

Kiedy zaczęłam studiować było bardzo dużo dziewczyn, mój rok był żeński. (...) Tyle dziewczyn dookoła, a profesorskie nawyki zostały.

W konsekwencji poszukuje nowych kontekstów dla swojej pracy twórczej, punktów oporów wobec zastanych schematów uprawiania reżyserii, pragnie wypracować nowe zasady, zmieniające istniejące rozwiązania. 


\section{Uwagi końcowe}

Relacje z innymi przedstawicielami dziedziny zmieniają się wraz z rozwojem zawodowym, czyli - jak w prezentowanym modelu - wraz z nabywaniem doświadczenia i budowaniem autonomii artystycznej. W narracjach reżyserek znaczenie spotkanych osób interpretowane jest niejednoznacznie i zmienia się w zależności od etapu rozwoju zawodowego ${ }^{13}$. Rozmówczynie przywoływały osoby znaczące dla rozwoju własnej kariery, ale nie ma wśród tych osób, które byłyby zdecydowanie nazwane Mistrzami. Myślę, że można mówić o „mistrzu zbiorowym”, czyli osobach uprawiających reżyserię, bo inspirują rozmówczynie poprzez posiadany dorobek, osobowość, czynne wykonywanie zawodu, wprowadzają w świat kontaktów środowiskowych i instytucjonalnych (formalnych i nieformalnych). Jednocześnie wybrzmiewa w narracjach „buntowniczy” stosunek wobec wykładowców wyższych szkół filmowych, telewizyjnych i teatralnych. Interesujące jest również doświadczenie związane z mistrzami, które można określić jako „Nauczanie, jak nie ...”: jak nie tworzyć, jak nie rozwijać się, jak czegoś nie robić. Opowieści o innych stają się tłem dla opowieści o podmiotowych działaniach reżyserek - podejmowanych decyzjach, predyspozycjach do zawodu, realiach pracy twórczej. Co nie znaczy, że inni nie przyczyniają się do rozwoju zawodowego, wręcz przeciwnie dynamizują indywidualny i grupowy (np. ekipa filmowa) proces twórczy, pomagają doprecyzować pomysły twórcze, opracować temat. Pełnią ostatecznie rolę katalizatorów procesu twórczego. Narracje reżyserek to przede wszystkim opowieści o podmiotowości i budowaniu niezależności artystycznej.

\section{Bibliografia}

Becker H. (1982) Art Worlds, Berkeley-Los Angeles, University of California Press.

Bertaux D. (2012) Analiza pojedynczych przypadków (au cas par cas) w: Metoda biograficzna w socjologii, K. Kaźmierska (red.), Kraków, Zakład Wydawniczy „NOMOS”, s. 309-333.

Całek A. (2012) Adam Mickiewicz - Juliusz Słowacki. Psychobiografia naukowa, Kraków, Wydawnictwo UJ.

Całek A. (2013) Biografia naukowa: od koncepcji do narracji. Interdyscyplinarność, teorie, metody badawcze, Kraków, Wydawnictwo UJ.

Csíkszentmihályi M. (1996) Creativity. Flow and the psychology of discovery and invention, New York, HarperPerennial.

${ }^{13}$ Podobną prawidłowość opisuje Howard Gardner (za: Całek 2012, 2013). 
Cyrański B. (2016) Interpretacja biografii zawodowej jako przykład zastosowania interpretacji hermeneutycznej w: Biograficzne badania nad twórczością. Teoria i empiria, M. Modrzejewska-Świgulska (red.), Łódź, Wydawnictwo UŁ, s. 121-137.

Denzin N. K. (1966) The Significant Others of a College Population, „The Sociological Quarterly", 7/3, s. 298-310.

Denzin N. K., Lincoln Y. S. (2009) Wprowadzenie. Dziedzina i praktyka badań jakościowych w: Metody badań jakościowych, N. K. Denzin, Y. S. Lincoln (red.), tłum. K. Podemski, Warszawa, Wydawnictwo Naukowe PWN, s. 19-75.

Ferenc T. (2012) Artysta jako obcy. Socjologiczne studium artystów polskich na emigracji, Łódź, Wydawnictwo UŁ.

Flick U. (2010) Projektowanie badania jakościowego, Warszawa, Wydawnictwo Naukowe PWN.

Frankfort-Nachmias Ch., Nachmias D. (2001) Metody badawcze w naukach społecznych, Poznań, Wydawnictwo Zysk i S-ka.

Galenson D. W. (2009) Old masters and young geniuses: The two life cycles of human creativity, „Journal of Applied Economics”, 12/1, s. 1-9.

Gardner H. (1988) Creative lives and creative works: a synthetic scientific approch w: R. J. Sternberg, The nature of creativity. Contemporary psychological perspectives, Cambridge, University Press, s. 298-321.

Gardner H. (1993) Creating minds. An Anatomy of Creativity Seen Through the Lives of Freud, Einstein, Picasso, Stravinsky, Eliot, Graham and Gandhi, New York, Basic Books A Member of The Perseus Books Group.

Iwińska K. (2015) Być i działać w społeczeństwie. Dyskusja wokół teorii podmiotowego sprawstwa, Kraków, Zakład Wydawniczy NOMOS.

Kafar M. (2011) Biograficzne epifanie w kontekście tworzenia podstaw jakościowego kolektywu myślowego w: Biografie naukowe. Perspektywa interdyscyplinarna, M. Kafar (red.), Łódź, Wydawnictwo UŁ, s. 37-66.

Kaufman J.-C. (2010) Wywiad rozumiejący, Warszawa, Oficyna Naukowa.

Konecki K. T. (2000) Studia z metodologii badań jakościowych. Teoria ugruntowana, Warszawa, Wydawnictwo Naukowe PWN.

Kvale S. (2004) Interviews. Wprowadzenie do jakościowego wywiadu badawczego, tłum. S. Zabielski, Białystok, Trans Humana.

Lutyński J. (2000) Metody badań społecznych. Wybrane zagadnienia, Łódź, Łódzkie Towarzystwo Naukowe. 
Miles B. M., Huberman A. M. (2000) Analiza danych jakościowych, Białystok, Wydawnictwo Trans Humana.

Miller E. M., Cohen L. M. (2012) Engendering Talent in Others: Expanding Domains of Giftedness and Creativity, „Roeper Review”, 34/2, s. 104-113.

Modrzejewska-Świgulska M. (2014) Kapral i poeta... Biograficzne uwarunkowania dróg zawodowych reżyserek w: Biograficzne badania nad twórczościq̨. Teoria i empiria, M. Modrzejewska-Świgulska (red.), Łódź, Wydawnictwo UŁ, s. 139-151.

Modrzejewska-Świgulska M. (2016) Realia pracy twórczej na przykładzie polskich reżyserek w: Kreatywność: między mitami, stereotypami a rzeczywistościq, I. Pufal-Struzik, Z. Okraj (red.), Kielce, Wydawnictwo UJK.

Modrzejewska-Świgulska M. (2018) Professional Competences. Reconstruction of the Opinions of Polish Female Directors, „Creativity. Theories - Research - Applications”, 5/1, s. 72-83.

Nęcka E. (2002) Psychologia twórczości, Gdańsk, Wydawnictwo GWP.

Okraj Z. (2017) Znaczenie rodziny w pracy wybitnych twórców $w$ perspektywie teorii. The Evolving Systems Approach to Creative Work Howarda E. Grubera, "Społeczeństwo i Rodzina", nr 3/52, s. 51-64.

Okraj Z., Modrzejewska-Świgulska M. (2018) Jedna teoria - dwie inspiracje badawcze. Relacje $z$ badań prowadzonych $z$ wykorzystaniem podejścia teoretyczno-metodologicznego Howarda E. Grubera, „Nauki o Wychowaniu. Studia Interdyscyplinarne”, nr $7 / 2$, s. 159-170.

Simonton D. K. (2010) Geniusz, tłum. M. Godyń, Warszawa, Wydawnictwo APS.

Stasiakiewicz M. (1999) Twórczość i interakcja, Poznań, Wydawnictwo Uniwersytetu im. A. Mickiewicza.

Szmidt K. J. (2013) Pedagogika twórczości, Sopot, Gdańskie Wydawnictwo Psychologiczne.

Szmidt K. J. (2017) Edukacyjne uwarunkowania rozwoju kreatywności, Łódź, Wydawnictwo Uniwersytetu Łódzkiego.

Szmidt K. J. (2019) ABC kreatywności. Kontynuacje, Warszawa, Difin.

Szmidt K. J., Modrzejewska-Świgulska M. (2011) Psychopedagogiczne badania nad twórczościq - krytyczny przegląd wybranych stanowisk w: Uczenie się z biografii innych, E. Dubas, W. Świtalski, Łódź, Wydawnictwo UŁ. 
Ślęzak I. (2009) Stawanie się poetą. Analiza interakcjonistyczno-symboliczna, „Przegląd Socjologii Jakościowej" monografie, t. 1, nr 1.

Talarczyk-Gubała M. (2013a) Biały Mazur. Kino kobiet w polskiej kinematografii, Poznań, Galeria Miejska Arsenał.

Talarczyk-Gubała M. (2013b) Wszystko o Ewie. Filmy Barbary Sass a kino kobiet $w$ drugiej połowie XX wieku, Szczecin, Wydawnictwo Naukowe Uniwersytetu Szczecińskiego.

Tokarz A. (2005) Motywacja jako warunek aktywności twórczej w: W poszukiwaniu zastosowań psychologii twórczości, A. Tokarz (red.), Kraków, Wydawnictwo UJ, s. 51-72.

Urbaniak-Zając D., Kos E. (2013) Badania jakościowe w pedagogice, Warszawa, Wydawnictwo Naukowe PWN.

Wagner I. (2005) Sprzężenie karier. Konstrukcja karier w środowiskach artystycznych i intelektualnych, „Przegląd Socjologii Jakościowej”, t. I, nr 1, s. 20-41.

Wejbert-Wąsiewicz E. (2015b) Niepokorne reżyserki kina polskiego w: Kobiety niepokorne. Reformatorki - Buntowniczki - Rewolucjonistki, I. Desperak, I. Kuźma (red.), Łódź, Wydawnictwo Uniwersytetu Łódzkiego, s. 253-264.

\section{Źródła internetowe}

Chrupała-Pniak M., Grabowski D. (2016) Skala motywacji zewnętrznej i wewnętrznej do pracy (WEIMS-PL). Wstępna charakterystyka psychometryczna polskiej wersji kwestionariusza Work Extrinsic and Intrinsic Motivation Scale (WEIMS), „Psychologia Społeczna”, nr 11/3, s. 339-355, https://www.researchgate.net/profile/ [dostęp: 08.2019].

Lebuda I., Csíkszentmihályi M. (2018) All You Need Is Love: The Importance of Partner and Family Relations to Highly Creative Individuals' Well-Being and Success, „Journal of Creative Behavior", https//doi.org/10.1002/jocb.348 [dostęp: 07.2019].

Myszka-Strychalska (2017) Koncepcje rozwoju zawodowego - przegląd wybranych stanowisk teoretycznych, https://repozytorium.ukw.edu.pl/bitstream/handle/item/ 5461/Koncepcje\%20rozwoju\%20zawodowego.pdf?sequence=1\&isAllowed=y [dostęp: 08.2019].

Tomasik K. (2004) Polskie reżyserki filmowe 1919-2002, „Kultura i Historia”, nr 6, http://www.kulturaihistoria.umsc.lublin.pl/archives/179 [dostęp: 09.2017].

Wejbert-Wąsiewicz E. (2015a) Filmy kobiet. Zmiany, zwroty $i$ „szklany sufit” $w$ kinematografii polskiej przed i po 1989, „Sztuka i Demokracja”, http://cejsh.icm.edu.pl/ cejsh/element/bwmeta1.element.desklight-5fb86d41-2411-43f1-841f cbfaef1eb965 [dostęp: 04.2018]. 